University of Nebraska - Lincoln

DigitalCommons@University of Nebraska - Lincoln

USDA National Wildlife Research Center - Staff Publications
U.S. Department of Agriculture: Animal and Plant Health Inspection Service

2011

\title{
Effect of GonaConTM vaccine on black-tailed prairie dogs: Immune response and health effects
}

\author{
C. A. A. Yoder \\ National Wildlife Research Center, christi.yoder@aphis.usda.gov \\ Lowell A. Miller \\ USDA/APHIS/Wildlife Services' National Wildlife Research Center, Fort Collins, CO, \\ lowell.a.miller@aphis.usda.gov
}

Follow this and additional works at: https://digitalcommons.unl.edu/icwdm_usdanwrc

Yoder, C. A. A. and Miller, Lowell A., "Effect of GonaConTM vaccine on black-tailed prairie dogs: Immune response and health effects" (2011). USDA National Wildlife Research Center - Staff Publications. 1386. https://digitalcommons.unl.edu/icwdm_usdanwrc/1386

This Article is brought to you for free and open access by the U.S. Department of Agriculture: Animal and Plant Health Inspection Service at DigitalCommons@University of Nebraska - Lincoln. It has been accepted for inclusion in USDA National Wildlife Research Center - Staff Publications by an authorized administrator of DigitalCommons@University of Nebraska - Lincoln. 


\title{
Effect of GonaCon ${ }^{\mathrm{TM}}$ vaccine on black-tailed prairie dogs: Immune response and health effects
}

\author{
Christi A. Yoder*, Lowell A. Miller \\ National Wildlife Research Center, 4101 LaPorte Avenue, Fort Collins, CO 80521, USA
}

\section{A R T I C L E I N F O}

\section{Article history:}

Received 15 January 2010

Received in revised form 14 October 2010

Accepted 20 October 2010

Available online 4 November 2010

\section{Keywords:}

Antibody titer

Blood chemistry

Contraception

Cynomys ludovicianus

GonaCon ${ }^{\mathrm{TM}}$

Prairie dogs

\begin{abstract}
A B S T R A C T
Management of prairie dogs in the past has included poisoning, fumigants, barriers, and relocation. Because of the diverse attitudes related to prairie dog management, nonlethal methods that allow the existence of prairie dogs but help minimize damage related to population growth need to be developed. GonaCon $^{\mathrm{TM}}$ is an immunocontraceptive vaccine that elicits antibodies to native $\mathrm{GnRH}$; this prevents the secretion of reproductive hormones necessary for sperm and oocyte production. Prairie dogs were vaccinated with $0.1,0.2$, or $0.4 \mathrm{~mL}$ of the GonaCon ${ }^{\mathrm{TM}}$ emulsion intramuscularly in the upper thigh containing 100,200 , or $400 \mu \mathrm{g}$ GnRH conjugate, respectively. Control animals were vaccinated with $0.4 \mathrm{~mL}$ saline emulsion in the upper thigh. Blood samples $(\leq 1 \mathrm{~mL})$ were taken from the femoral vein once pretreatment and at 1, 2, 3, 4, 6, and 15 months post-vaccination. Age (adult or juvenile) did not affect immune response to GonaCon ${ }^{\mathrm{TM}}$. Antibody titers were higher in the 200 and $400 \mu \mathrm{L}$ GonaCon ${ }^{\mathrm{TM}}$ groups than in the $100 \mu \mathrm{L}$ group, and there was no difference between the 200 and $400 \mu \mathrm{L}$ GonaCon ${ }^{\mathrm{TM}}$ groups. No adverse effects of GonaCon ${ }^{\mathrm{TM}}$ were noted on weight or blood chemistry parameters during the study. GonaCon ${ }^{\mathrm{TM}}$ will likely contracept prairie dogs for $\geq 1$ year in the field using either 200 or $400 \mu$ g conjugate. GonaCon ${ }^{\mathrm{TM}}$ could be incorporated into management plans to help maintain prairie dog populations while reducing habitat degradation due to overpopulation.
\end{abstract}

Published by Elsevier Ltd.

\section{Introduction}

Research of wildlife contraceptives has resulted in the registration of OvoControl for Canada geese (Branta canadensis) and pigeons (Columba livia), and GonaCon ${ }^{\mathrm{TM}}$ for white-tailed deer (Odocoileus virginianus) [1]. Registrations of these products for other species will likely occur. As wildlife contraceptives become available for more species, information on efficacy and health effects will be needed to determine their appropriateness for particular species.

Discussions as to what characteristics a wildlife contraceptive should have are not new [2,3]. One characteristic which is unarguably important, and generally agreed upon, is the lack of negative health effects of a contraceptive in the target species [1-3]. To date, only a handful of studies have examined the effects of immunocontraceptives on blood chemistry. A porcine zona pellucida immunocontraceptive vaccine administered to white-tailed deer did not produce any significant changes in blood chemistry [4]. GonaCon $^{\mathrm{TM}}$, and a previous formulation of this vaccine, also did not alter blood chemistry in treated white-tailed deer [5,6]. Although

\footnotetext{
* Corresponding author. Tel.: +1 970266 6153; fax: +1 9702666153.

E-mail address: christi.yoder@aphis.usda.gov (C.A. Yoder).
}

GonaCon ${ }^{\mathrm{TM}}$ vaccine formulations have been tested in California ground squirrels (Spermophilus beecheyi) and Norway rats (Rattus norvegicus), these studies did not examine blood chemistry $[7,8]$. However, no overt adverse effects were noted in these species.

Black-tailed prairie dogs (Cynomys ludovicianus) are one of five species of prairie dogs found in North America. Their habitat covers the Great Plains from northern Mexico to southern Canada. Although they currently occupy less than $5 \%$ of their original range, they are frequently the subject of controversy [9-11]. Because of their influence on biodiversity, prairie dogs are considered keystone species [12]. In their role as a keystone species, prairie dogs serve as prey, and their burrows provide shelter for several species [13]. The role of urban prairie dogs as keystone species depends on a number of factors, including colony size and makeup of the surrounding urban environment [14]. Because of the limited opportunities for dispersal in urban environments, prairie dogs can exist in densities up to five times higher than in rural environments, which can lead to conflicts with humans $[15,16]$. In the urban environment, this includes degradation of habitats through burrowing and grazing, damage to ornamental vegetation, and spreading of colonies into human neighborhoods [17,18].

Prairie dog habitat along the Front Range in Colorado is highly fragmented, and many colonies in urban areas exist in small natural areas [19]. Some of these areas are designated as natural areas by 
municipalities, and others exist in highway right-of-ways or vacant lots. Management of prairie dogs in urban areas is highly controversial, and municipalities are charged with maintaining colonies while minimizing damage associated with overgrazing and colony expansion [18].

In 1991, prairie dog populations in Fort Collins, Colorado occupied 836 ha, $82 \%$ of which occurred in natural areas [20]. A survey of Fort Collins residents in 1993 showed residents that experienced no prairie dog related damage supported relocation over lethal control. Residents experiencing conflicts with prairie dogs were more likely to support lethal control measures [17]. Both groups of stakeholders were willing to support a combination of control and preservation, rating protection of property and the presence of raptors as important outcomes of management. Because of the diverse attitudes related to prairie dog management, nonlethal methods that allow the existence of prairie dogs but help minimize damage related to population growth need to be developed.

Management of prairie dogs in the past has included poisoning, fumigants, barriers, and relocation [21-23]. Barriers and relocation tend to be expensive, can be ineffective, and are dependent on available sites [21,24-26]. The cost of control can outweigh the benefits [27]. Survival and reproductive rates increase after a population reduction, either through lethal control or natural means such as a plague outbreak $[28,29]$. Contraception may provide an effective and acceptable alternative to help minimize colony expansion.

Immunocontraception is one such promising contraceptive technique. By conjugating an endogenous peptide to a foreign carrier protein (e.g. mollusk proteins), the body is induced to produce antibodies to its own hormones. One such immunocontraceptive vaccine uses gonadotropin-releasing hormone (GnRH). The hypothalamus releases GnRH which stimulates the release of luteinizing hormone ( $\mathrm{LH})$ from the anterior pituitary. The gonads produce testosterone and progesterone in response to LH stimulation, which stimulate the production of sperm and oocytes. When an animal is injected with the GnRH vaccine, anti-GnRH antibodies bind to endogenous $\mathrm{GnRH}$, preventing it from binding in the anterior pituitary and releasing LH. As a result, production of testosterone and progesterone is decreased, and reproduction is reduced.

In the past, immunocontraceptive vaccines required the use of two or more vaccinations. Recently, a single-shot vaccine has been developed (GonaCon ${ }^{\mathrm{TM}}$ ) that is efficacious for $\geq 2$ years [30]. The GnRH immunocontraceptive vaccine has been successfully used on rats (Rattus norvegicus) and California ground squirrels (Spermophilus beecheyi) for $\geq 2$ years $[7,8]$. GonaCon ${ }^{\mathrm{TM}}$ has not been tested on black-tailed prairie dogs. Therefore, a laboratory study was conducted to determine whether the GonaCon ${ }^{\mathrm{TM}}$ vaccine would elicit an antibody titer response in black-tailed prairie dogs. Further objectives of this study were to determine whether higher doses of the vaccine elicited higher and more prolonged antibody titers, and whether the vaccine altered blood chemistry profiles.

\section{Materials and methods}

Prairie dogs were captured at several locations in Boulder County, CO, USA under a Colorado Division of Wildlife Scientific Collection Permit (06TR809). All animals were dusted with a pyrethrin-based flea powder and metal ear tags were attached to both ears of each animal upon arrival at the National Wildlife Research Center. In addition, each animal was injected with a PIT tag after quarantine because of the number of lost ear tags. All animals were quarantined for 14 days, and prairie dogs were dusted again with a pyrethrin-based flea powder at the end of the quarantine period.

Because the prairie dogs were trapped late in the year, it was difficult to obtain a larger number of adults as was initially planned in the protocol. At the time of quarantine, there were 12 adult females, 9 adult males, 9 juvenile females, and 9 juvenile males. Prairie dogs were housed outdoors during quarantine where they were subject to ambient light and temperatures. Animals were kept in either $0.61 \mathrm{~m} \times 0.46 \mathrm{~m} \times 0.30 \mathrm{~m}$ or $0.46 \mathrm{~m} \times 0.46 \mathrm{~m} \times 0.30 \mathrm{~m}$ Tomahawk traps in covered outdoor facilities. Each trap was partially covered with burlap and a length of PVC pipe was provided as a hide for each animal.

During the experimental phase, prairie dogs were housed indoors in a Simulated Natural Environment room $\left(82.7 \mathrm{~m}^{2}\right)$. Prairie dogs were maintained on pine wood chips and were provided with PVC pipes and wooden pallets for hides. Prairie dogs were maintained on a $12 \mathrm{~L}: 12 \mathrm{D}$ light schedule, $15.6-21.1^{\circ} \mathrm{C}$, ambient humidity conditions, and were fed a combination of carrots, apples, grass hay and rodent block.

Prairie dogs were grouped by first by sex, then age, and finally they were ranked by weight. The SAS statistical program was used to randomly assign approximately equal numbers of males and females of both age groups to treatment groups based on weight [31]. The four heaviest adult males were randomly assigned to one of the four treatment groups and the four heaviest adult females were randomly assigned to one of the four treatment groups. This process was repeated using the next four heaviest adult males and the next four heaviest adult females until all adult males and females were assigned to treatment groups. The same process was repeated for male and female juveniles.

The study consisted of four treatment groups as follows: (1) control, vaccinated with saline-AdjuVac ${ }^{\mathrm{TM}}$ only; (2) treated, vaccinated with $0.1 \mathrm{~mL}$ GonaCon ${ }^{\mathrm{TM}}-$ AdjuVac $^{\mathrm{TM}}$ (100 $\mu$ g conjugate); (3) treated, vaccinated with $0.2 \mathrm{~mL}$ GonaCon $^{\mathrm{TM}}-$ AdjuVac $^{\mathrm{TM}}$ (200 $\mu \mathrm{g}$ conjugate); (4) treated, vaccinated with $0.4 \mathrm{~mL}$ GonaCon $^{\mathrm{TM}}-$ AdjuVac $^{\mathrm{TM}}$ ( $400 \mu \mathrm{g}$ conjugate). There were 10 , 10,10 , and 9 prairie dogs in the $0,100,200$, and $400 \mu$ g conjugate groups, respectively. The control group consisted of 5 females ( 3 adults, 2 juveniles) and 5 males ( 2 adults, 3 juveniles). The $100 \mu \mathrm{g}$ conjugate group consisted of 6 females ( 3 adults, 3 juveniles) and 4 males ( 2 adults, 2 juveniles). The $200 \mu \mathrm{g}$ conjugate group consisted of 5 females ( 3 adults, 2 juveniles) and 5 males ( 3 adults, 2 juveniles). The $400 \mu \mathrm{g}$ conjugate group consisted of 5 females ( 3 adults, 2 juveniles) and 4 males ( 2 adults, 2 juveniles).

The $C$ terminal end of GnRH (Global Peptide, Fort Collins, CO, USA) was conjugated to a maleimide activated carrier (mollusk protein). GonaCon ${ }^{\mathrm{TM}}$ was made by mixing the conjugate with an equal volume of AdjuVac ${ }^{\mathrm{TM}}$ and passing the mixture through a Microfluidics M110L Microfluidizer® Processor (Newton, MA). GonaCon ${ }^{\mathrm{TM}}$ contains $1000 \mu \mathrm{g}$ conjugate $/ \mathrm{mL}$. Prairie dogs were vaccinated with $0.1,0.2$, or $0.4 \mathrm{~mL}$ of the GonaCon ${ }^{\mathrm{TM}}$ emulsion intramuscularly in the upper thigh. Control animals were vaccinated with $0.4 \mathrm{~mL}$ saline-AdjuVac ${ }^{\mathrm{TM}}$ emulsion in the upper thigh. Both control and treated animals only received a single injection each. The injection site was swabbed with isopropyl alcohol prior to injection.

Blood samples $(\leq 1 \mathrm{~mL}$ ) were taken from the femoral vein once pretreatment and at 1, 2, 3, 4, 6, and 15 months post-vaccination. Prairie dogs were restrained for bleeding using a canvas cone that prevented the animal from turning around, but allowed normal respiration. Animals were weighed each time a blood sample was obtained using the Ohaus ChampII/CD-11 Indicator Scale (Ohaus Corporation, Florham Park, NJ, USA).

At approximately 1 month post-treatment, it was observed that many prairie dogs had fur missing from their backs. Because of this, each animal was closely inspected for signs of molting and reproductive development. Specifically, the location where hair was missing was recorded as either dorsal, ventral, or lateral, and an estimate was made as to percent hair loss. Females were examined for signs of a swollen vulva, teat development, or lactation. Males were examined for signs of scrotal development and pigmentation. 


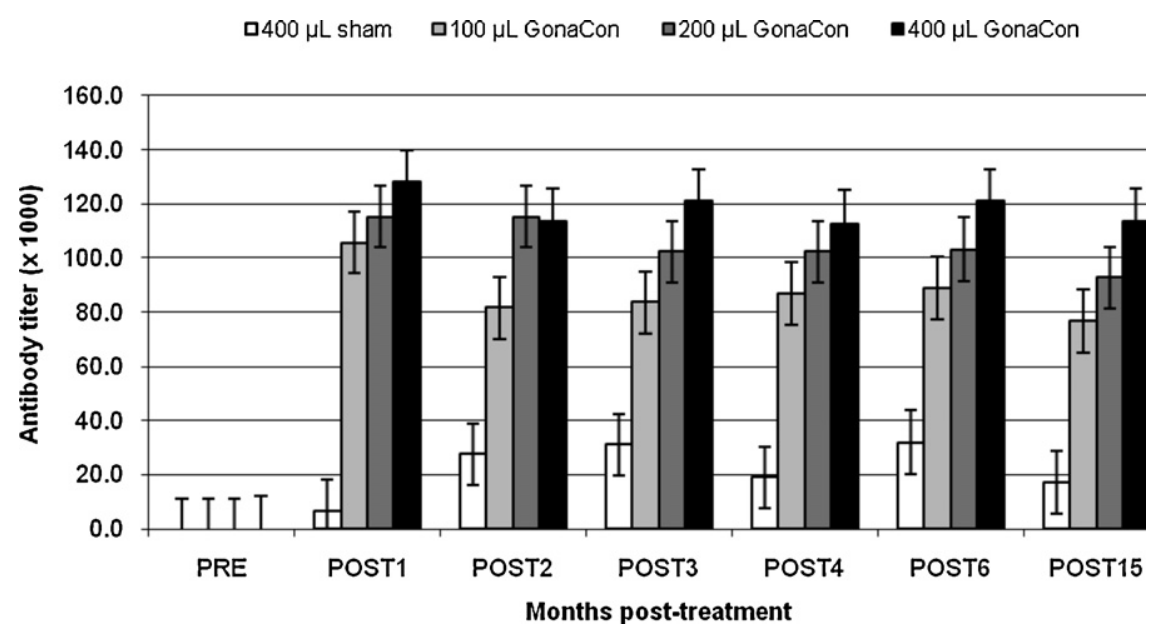

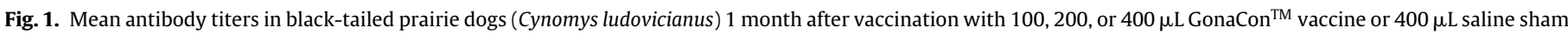
vaccine. Mean values were obtained by averaging antibody titers within treatment groups at each time period.

Anti-prairie dog IgG antibodies were raised in a New Zealand rabbit. Blood was obtained from the rabbit and the serum purified for rabbit IgG using the NAb ${ }^{\mathrm{TM}}$ Spin Kit (Pierce Biotechnology, Rockford, IL, USA). The purified rabbit IgG contained anti-prairie dog IgG antibodies that were used for enzyme-linked immunosorbent assays (ELISA) as described below.

Plasma samples were analyzed by ELISA for GnRH antibody titers. Prairie dog serum $(50 \mu \mathrm{L})$ was serially diluted from 1:1000 to $1: 128,000$ on a 96 -well microtiter plate. Antibody titers were determined by adding rabbit anti-prairie dog antibody $(1: 10,000)$ to each well. Plates were washed and goat anti-rabbit antibody (1:6000) labeled with horseradish peroxidase from Sigma (product no. A-6154) was added to each well. Color was developed with tetramethylbenzidine (TMB; Sigma T-3405)/phosphate citrate buffer (Sigma P-9305). Color was proportional to the anti-GnRH antibody titer. In addition to PBS blank wells, a negative control and a positive control were included on each plate. Because of the large amount of background noise in the prairie dog samples, all optical densities (OD) for the prairie dogs were control corrected using the pretreatment samples at each dilution. The endpoint titer was determined to be the last row for which an OD existed in the transformed data.

A general blood chemistry panel was performed on each pretreatment sample, and each sample taken 6 months postvaccination. Samples were analyzed on a VetScan Blood Chemistry Analyzer (Abaxis, Union City, CA, USA). Because blood clotted too quickly during the pretreatment blood draw, hematocrit data was only obtained for blood drawn 6 months post-treatment. Hematocrit was determined in duplicate, and the results averaged for statistical analysis.

Antibody titers, blood chemistries, and body weights were analyzed as repeated measures mixed effects models using prairie dogs as random effects, and treatments as fixed effects (PROC MIXED) [31]. Means separations were carried out using PDMIX800 [32]. Hematocrit and percent hair loss were analyzed using analysis of variance (PROC GLM) because there was only a single data point for each animal [31]. Mean and standard errors of the mean for these two variables were obtained using PROC MEANS [31].

\section{Results}

Age (adult or juvenile) did not affect immune response to GonaCon $^{\mathrm{TM}}\left(F_{1,31}=1.18, P=0.2850\right.$; Fig. 1$)$; therefore, juveniles and adults were grouped together for further analysis. Antibody titers were higher in the treatment groups than in the control group
$\left(F_{3,47}=18.98, P<0.0001\right)$. Titers were significantly higher in the $400 \mu \mathrm{g}$ group than in the $100 \mu \mathrm{g}$ group. Titers were lower overall 15 months post-treatment than at 1 month post-treatment $\left(F_{6,193}=70.33, P<0.0001\right)$.

There were no differences among groups for alkaline phosphatase $\left(F_{3,28}=0.12, \quad P=0.9458\right)$, alanine aminotransferase $\left(F_{3,19}=0.521, P=0.6806\right)$, total bilirubin $\left(F_{3,29}=2.33, P=0.0948\right)$, glucose $\left(F_{3,29}=0.59, P=0.6240\right)$, or globulin $\left(F_{3,28}=0.09, P=0.9665\right)$. All indicators of liver function (alkaline phosphatase, alanine aminotransferase, total bilirubin, glucose) except globulin were decreased at 6 months post-treatment from the pretreatment values $(P<0.05$; Table 1$)$. Globulin values were approximately the same during the pretreatment period as during the period 6 months post-treatment $\left(F_{1,19}=3.26 ; P=0.0871\right)$.

Of the indicators of kidney function (albumin, amylase, blood urea nitrogen, creatinine, total protein), only blood urea nitrogen varied among treatment groups $\left(F_{3,24}=3.74 ; P=0.0244\right.$; Table 2). There were no differences among groups for albumin $\left(F_{3,19}=1.3, P=0.3047\right)$, amylase $\left(F_{3,25}=0.45, P=0.7226\right)$, creatinine $\left(F_{3.19}=0.77, P=0.5273\right)$, or total protein $\left(F_{3,23}=0.43, P=0.7364\right)$. Albumin, total protein, and blood urea nitrogen were increased at 6 months post-treatment from the pretreatment values $(P<0.05)$. Amylase was decreased at 6 months post-treatment from the pretreatment values $\left(F_{1,15}=14.79 ; P=0.0017\right)$. Creatinine values were approximately the same during the pretreatment period as during the period 6 months post-treatment $\left(F_{1,21}=2.84 ; P=0.1071\right)$.

There were no differences among groups for calcium $\left(F_{3,29}=1.69, P=0.1918\right)$, phosphorus $\left(F_{3,26}=0.44, P=0.7294\right)$, potassium $\left(F_{3,17}=1.05, P=0.3955\right)$, or sodium $\left(F_{3,24}=1.03, P=0.3952\right)$. Phosphorus $\left(F_{1,19}=2.91, P=0.1039\right)$ and sodium $\left(F_{1,25}=0.02\right.$, $P=0.9031)$ values were approximately the same during the pretreatment period as during the period 6 months post-treatment (Table 3). Calcium and potassium values were increased at 6 months post-treatment from the pretreatment values $(P<0.05)$. Hematocrit did not vary among treatment groups $\left(F_{3,26}=0.24\right.$, $\mathrm{df}=3, P=0.8662$; Table 4 ).

Weights did not vary among treatment groups $\left(F_{3,35}=0.57\right.$, $P=0.6367)$, but increased in all groups until 6 months posttreatment, then decreased slightly $\left(F_{6,35}=71.96, P<0.0001\right.$; Fig. 2$)$. The percentage hair loss did not vary among treatment groups $\left(F_{3,35}=0.40, \mathrm{df}=3, P=0.7564\right.$; Table 5$)$. Among treatment groups, $70,50,40$, and $56 \%$ of the animals were molting in the control, 100 , 200 , and $400 \mu \mathrm{L}$ groups, respectively. Molting occurred primarily on the dorsal and ventral surfaces, and most of the animals showed signs of molting on two surfaces. None of the animals examined were in reproductive condition. 
Table 1

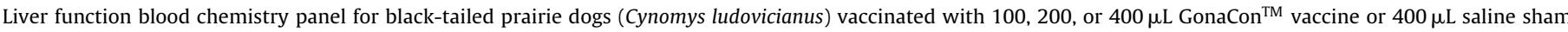
vaccine. Mean values were obtained by averaging values within treatment groups either pretreatment or 6 months post-treatment.

\begin{tabular}{|c|c|c|c|c|c|c|c|c|c|c|}
\hline \multirow[t]{2}{*}{ Group/phase } & \multicolumn{2}{|c|}{ Alkaline phosphatase (U/L) } & \multicolumn{2}{|c|}{$\begin{array}{l}\text { Alanine aminotransferase } \\
(\mathrm{U} / \mathrm{L})\end{array}$} & \multicolumn{2}{|c|}{ Total bilirubin $(\mu \mathrm{mol} / \mathrm{L})$} & \multicolumn{2}{|c|}{ Glucose $(\mathrm{mmol} / \mathrm{L})^{\mathrm{a}}$} & \multicolumn{2}{|c|}{ Globulin $(\mathrm{g} / \mathrm{L})^{\mathrm{a}}$} \\
\hline & $\bar{x} \pm$ SEM & $n$ & $\bar{x} \pm$ SEM & $n$ & $\bar{x} \pm$ SEM & $n$ & $\bar{x} \pm$ SEM & $n$ & $\bar{x} \pm$ SEM & $n$ \\
\hline Sham/PRE ${ }^{b}$ & $95.9 \pm 7.8$ & 7 & $48.4 \pm 6.0$ & 7 & $7.6 \pm 0.3$ & 7 & $9.9 \pm 0.6$ & 7 & $45.4 \pm 1.6$ & 7 \\
\hline Sham/POST ${ }^{b}$ & $55.9 \pm 10.0$ & 3 & $26.4 \pm 8.7$ & 3 & $3.4 \pm 0.6$ & 2 & $5.6 \pm 0.8$ & 3 & $38.1 \pm 2.4$ & 3 \\
\hline $100 \mu \mathrm{L} / \mathrm{PRE}$ & $85.8 \pm 7.7$ & 6 & $47.6 \pm 6.3$ & 6 & $7.4 \pm 0.4$ & 6 & $9.0 \pm 0.6$ & 6 & $42.6 \pm 1.7$ & 6 \\
\hline $100 \mu \mathrm{L} / \mathrm{POST}$ & $54.7 \pm 7.4$ & 7 & $25.5 \pm 5.9$ & 7 & $2.4 \pm 0.4$ & 5 & $6.7 \pm 0.5$ & 7 & $40.2 \pm 1.7$ & 6 \\
\hline $200 \mu \mathrm{L} / \mathrm{PRE}$ & $84.9 \pm 7.8$ & 6 & $43.0 \pm 6.3$ & 6 & $7.1 \pm 0.4$ & 6 & $8.5 \pm 0.6$ & 6 & $41.8 \pm 1.7$ & 6 \\
\hline $200 \mu \mathrm{L} / \mathrm{POST}$ & $55.8 \pm 7.8$ & 6 & $34.2 \pm 5.6$ & 8 & $2.6 \pm 0.6$ & 2 & $6.5 \pm 0.5$ & 8 & $43.0 \pm 1.7$ & 6 \\
\hline $400 \mu \mathrm{L} / \mathrm{PRE}$ & $86.0 \pm 7.4$ & 7 & $35.5 \pm 5.9$ & 7 & $7.6 \pm 0.3$ & 7 & $8.2 \pm 0.5$ & 7 & $41.7 \pm 1.6$ & 7 \\
\hline $400 \mu \mathrm{L} / \mathrm{POST}$ & $56.8 \pm 7.7$ & 6 & $25.8 \pm 6.3$ & 6 & $4.3 \pm 0.6$ & 2 & $5.9 \pm 0.6$ & 6 & $41.9 \pm 1.9$ & 5 \\
\hline
\end{tabular}

a Glucose and globulin are also indicative of kidney function [45].

b $\mathrm{PRE}=$ pretreatment; POST $=6$ months post-treatment.

Table 2

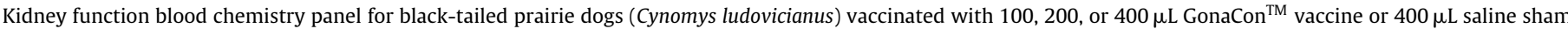
vaccine. Mean values were obtained by averaging values within treatment groups either pretreatment or 6 months post-treatment.

\begin{tabular}{|c|c|c|c|c|c|c|c|c|c|c|}
\hline \multirow[t]{2}{*}{ Group/phase } & \multicolumn{2}{|c|}{ Albumin $(\mathrm{g} / \mathrm{L})^{\mathrm{a}}$} & \multicolumn{2}{|l|}{ Amylase (U/L) } & \multicolumn{2}{|c|}{$\begin{array}{l}\text { Blood urea nitrogen } \\
(\mathrm{mmol} / \mathrm{L})^{\mathrm{a}}\end{array}$} & \multicolumn{2}{|c|}{ Creatinine $(\mu \mathrm{mol} / \mathrm{L})^{\mathrm{a}}$} & \multicolumn{2}{|c|}{ Total protein $(\mathrm{g} / \mathrm{L})^{\mathrm{a}}$} \\
\hline & $\bar{x} \pm$ SEM & $n$ & $\bar{x} \pm$ SEM & $n$ & $\bar{x} \pm$ SEM & $n$ & $\bar{x} \pm$ SEM & $n$ & $\bar{x} \pm$ SEM & $n$ \\
\hline Sham/PRE ${ }^{c}$ & $31.0 \pm 1.2$ & 7 & $139.6 \pm 10.4$ & 7 & $9.9 \pm 0.6$ & 7 & $68.2 \pm 4.9$ & 7 & $76.4 \pm 1.9$ & 7 \\
\hline Sham/POST ${ }^{\mathrm{C}}$ & $44.2 \pm 1.8$ & 3 & $123.5 \pm 13.2$ & 3 & $14.8 \pm 0.9$ & 3 & $89.0 \pm 7.5$ & 3 & $83.4 \pm 2.9$ & 3 \\
\hline $100 \mu \mathrm{L} / \mathrm{PRE}$ & $29.9 \pm 1.3$ & 6 & $149.2 \pm 11.8$ & 6 & $8.0 \pm 0.7$ & 6 & $67.8 \pm 5.3$ & 6 & $72.9 \pm 2.1$ & 6 \\
\hline $100 \mu \mathrm{L} / \mathrm{POST}$ & $43.1 \pm 1.3$ & 6 & $120.5 \pm 9.1$ & 7 & $12.3 \pm 0.6$ & 7 & $74.9 \pm 5.3$ & 6 & $84.3 \pm 1.9$ & 7 \\
\hline $200 \mu \mathrm{L} / \mathrm{PRE}$ & $31.7 \pm 1.3$ & 6 & $136.4 \pm 9.3$ & 6 & $9.1 \pm 0.7$ & 6 & $72.1 \pm 5.3$ & 6 & $72.8 \pm 2.1$ & 6 \\
\hline $200 \mu \mathrm{L} / \mathrm{POST}$ & $44.2 \pm 1.3$ & 6 & $110.8 \pm 10.6$ & 8 & $12.7 \pm 0.6$ & 8 & $73.7 \pm 5.3$ & 6 & $88.2 \pm 1.8$ & 8 \\
\hline $400 \mu \mathrm{L} / \mathrm{PRE}$ & $33.2 \pm 1.2$ & 7 & $133.5 \pm 9.8$ & 7 & $9.1 \pm 0.6$ & 7 & $78.5 \pm 4.9$ & 7 & $74.5 \pm 1.9$ & 7 \\
\hline $400 \mu \mathrm{L} / \mathrm{POST}$ & $44.3 \pm 1.4$ & 5 & $113.0 \pm 10.5$ & 6 & $12.2 \pm 0.7$ & 6 & $76.1 \pm 5.8$ & 5 & $86.0 \pm 2.1$ & 6 \\
\hline
\end{tabular}

a Albumin, blood urea nitrogen, creatinine, and total protein are also indicative of liver function $[33,45]$.

b Amylase is also indicative of pancreatic function [36].

c $\mathrm{PRE}=$ pretreatment; $\mathrm{POST}=6$ months post-treatment.

Table 3

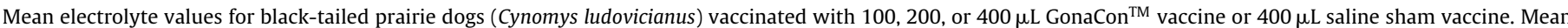
values were obtained by averaging values within treatment groups either pretreatment or 6 months post-treatment.

\begin{tabular}{|c|c|c|c|c|c|c|c|c|}
\hline \multirow[t]{2}{*}{ Group/phase } & \multicolumn{2}{|c|}{ Calcium (mmol/L) } & \multicolumn{2}{|c|}{ Phosphorus (mmol/L) } & \multicolumn{2}{|c|}{ Sodium $(\mathrm{mmol} / \mathrm{L})$} & \multicolumn{2}{|c|}{ Potassium $(\mathrm{mmol} / \mathrm{L})$} \\
\hline & $\bar{x} \pm$ SEM & $n$ & $\bar{x} \pm \mathrm{SEM}$ & $n$ & $\bar{x} \pm \mathrm{SEM}$ & $n$ & $\bar{x} \pm \mathrm{SEM}$ & $n$ \\
\hline Sham/PRE ${ }^{a}$ & $2.6 \pm 0.1$ & 7 & $2.3 \pm 0.2$ & 7 & $152.7 \pm 1.6$ & 7 & $5.7 \pm 0.3$ & 7 \\
\hline Sham/POST ${ }^{\mathrm{b}}$ & $2.8 \pm 0.1$ & 3 & $2.3 \pm 0.3$ & 3 & $150.9 \pm 2.5$ & 3 & $8.4 \pm 0.8$ & 1 \\
\hline $100 \mu \mathrm{L} / \mathrm{PRE}$ & $2.5 \pm 0.1$ & 6 & $2.1 \pm 0.2$ & 6 & $148.5 \pm 1.7$ & 6 & $5.0 \pm 0.3$ & 6 \\
\hline $100 \mu \mathrm{L} / \mathrm{POST}$ & $2.7 \pm 0.1$ & 7 & $2.3 \pm 0.2$ & 7 & $149.4 \pm 1.7$ & 6 & $7.7 \pm 0.4$ & 3 \\
\hline $200 \mu \mathrm{L} / \mathrm{PRE}$ & $2.6 \pm 0.1$ & 6 & $1.9 \pm 0.2$ & 6 & $150.4 \pm 1.7$ & 6 & $5.0 \pm 0.3$ & 6 \\
\hline $200 \mu \mathrm{L} / \mathrm{POST}$ & $2.8 \pm 0.1$ & 7 & $2.4 \pm 0.2$ & 8 & $152.5 \pm 1.7$ & 6 & $7.8 \pm 0.5$ & 2 \\
\hline $400 \mu \mathrm{L} / \mathrm{PRE}$ & $2.7 \pm 0.1$ & 7 & $1.9 \pm 0.2$ & 7 & $151.4 \pm 1.6$ & 7 & $4.9 \pm 0.3$ & 7 \\
\hline $400 \mu \mathrm{L} / \mathrm{POST}$ & $2.8 \pm 0.1$ & 6 & $2.1 \pm 0.2$ & 6 & $149.6 \pm 1.7$ & 6 & $7.5 \pm 0.5$ & 2 \\
\hline
\end{tabular}

a $\mathrm{PRE}=$ pretreatment

b POST $=6$ months post-treatment.

\section{Discussion}

One of the objectives of this study was to determine whether the GonaCon ${ }^{\mathrm{TM}}$ vaccine would elicit an antibody titer response in a dose-dependent manner in black-tailed prairie dogs. The immuno-

\section{Table 4}

Mean hematocrits (L/L) in black-tailed prairie dogs (Cynomys ludovicianus) 1 month after vaccination with either 100,200 , or $400 \mu \mathrm{LGonaCon}^{\mathrm{TM}}$ vaccine or $400 \mu \mathrm{L}$ saline sham vaccine. Mean values were obtained by averaging hematocrits within treatment groups; hematocrits were only determined at 6 months post-treatment. Mean values were not significantly different $(P<0.05)$.

\begin{tabular}{lcr}
\hline Group & Hematocrit $($ mean \pm SEM $)$ & $n$ \\
\hline Sham & $0.571 \pm 0.021$ & 5 \\
$100 \mu \mathrm{L}$ & $0.571 \pm 0.017$ & 7 \\
$200 \mu \mathrm{L}$ & $0.578 \pm 0.015$ & 10 \\
$400 \mu \mathrm{L}$ & $0.589 \pm 0.016$ & 8 \\
\hline
\end{tabular}

logical response of black-tailed prairie dogs was generally dose dependent with respect to the magnitude of the antibody titer. The longevity of the response appeared to be only slightly related to treatment. At 15 months post-treatment, mean antibody titers were $\geq 1: 77,000$ in all three treatment groups. Antibody titers $\geq 1: 128,000$ are likely to be contraceptive, whereas it is unknown

Table 5

Mean percent hair loss (\%) in black-tailed prairie dogs (Cynomys ludovicianus) 1 month after vaccination with either 100,200 , or $400 \mu \mathrm{L}$ GonaCon ${ }^{\mathrm{TM}}$ vaccine or $400 \mu \mathrm{L}$ saline sham vaccine. Mean values were not significantly different $(P<0.05)$. Mean values were obtained by averaging values within treatment groups.

\begin{tabular}{lcr}
\hline Group & Percent hair loss $($ mean \pm SEM) & $n$ \\
\hline Sham & $8.0 \pm 6.3$ & 10 \\
$100 \mu \mathrm{L}$ & $14.0 \pm 6.3$ & 10 \\
$200 \mu \mathrm{L}$ & $12.5 \pm 6.3$ & 10 \\
$400 \mu \mathrm{L}$ & $17.8 \pm 6.6$ & 9 \\
\hline
\end{tabular}




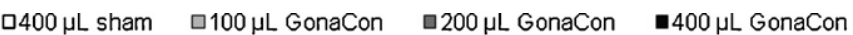

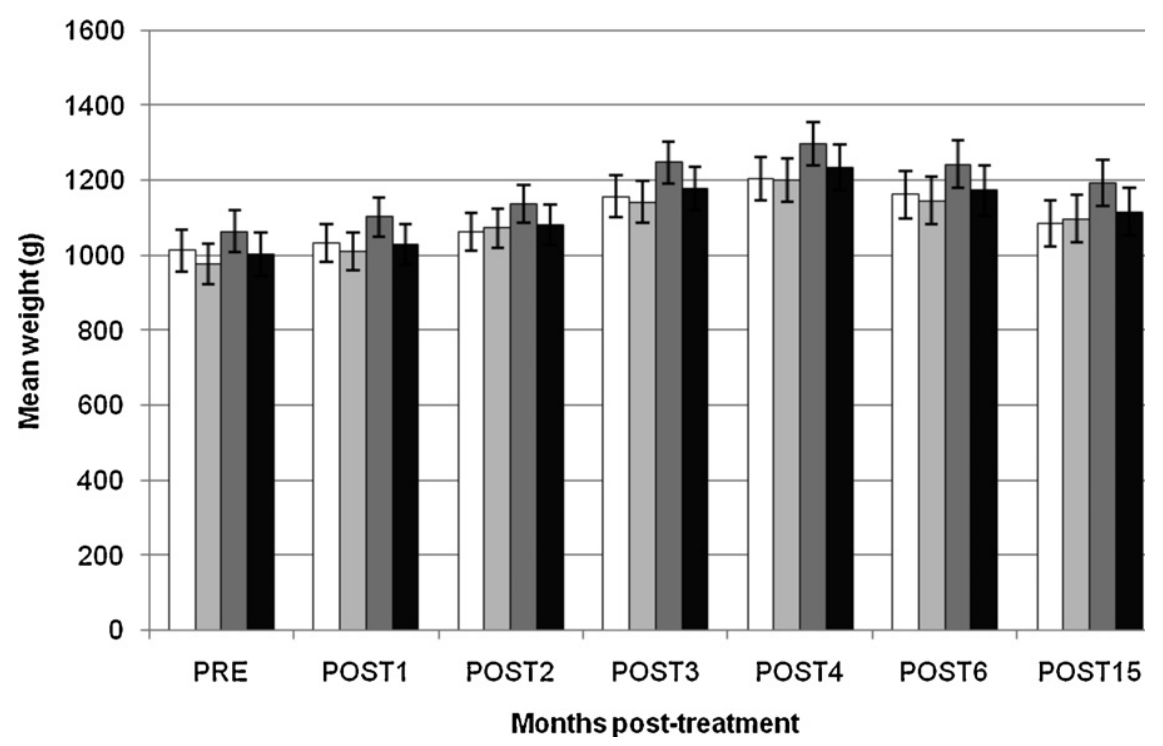

Fig. 2. Mean weights (g) of prairie dogs (Cynomys ludovicianus) vaccinated with 100,200 , or $400 \mu \mathrm{L}$ GonaCon ${ }^{\mathrm{TM}}$ vaccine or $400 \mu \mathrm{L}$ saline sham vaccine.

whether antibody titers of $1: 77,000$ would still be contraceptive. Because the average in the $400 \mu$ g group was $1: 114,000$, it is recommended this dose be used to test the vaccine efficacy in a field trial. Although the control group appeared to have low level antibody titers, this was likely due to cross reactivity of the rabbit anti-prairie dog antibody with something in the serum. To avoid this problem in the future, rabbit anti-prairie dog antibodies should be affinity purified prior to use in the ELISA.

GonaCon ${ }^{\mathrm{TM}}$ did not alter liver function in this study. Although repeated measures analysis did not find any significant differences among the groups, the $95 \%$ confidence intervals for total bilirubin indicate a near-significant effect. Post-treatment total bilirubin in the $400 \mu \mathrm{g}$ group was higher than the rest of the groups, but the control group had the second highest bilirubin level. This indicates the near-significant effect may be a spurious result.

All liver enzymes except globulin decreased post-treatment. Most clinical chemistry texts and journal articles are concerned with elevated liver enzymes as these indicate liver damage [33-35]. A variety of factors such as anticoagulants, exposure to fluorescent light, and metabolically active cells can cause falsely decreased alkaline phosphatase, total bilirubin, or glucose [36]. However, none of these factors seem likely as anticoagulants were not used, and blood samples were always collected in the same manner at approximately the same time of day.

There are no known physiologically significant causes of decreased alanine aminotransferase or total bilirubin [36]. Decreases in alkaline phosphatase can be caused by hypothyroidism or impaired metabolism of vitamin $B_{6}$, and decreased glucose can be caused by hepatic insufficiency [36,37]. A diagnosis of hepatic insufficiency does not seem to be supported because none of the other liver enzymes indicated this. Plasma glucose decreases in rats and mice with age, and this may be the cause of the decreased glucose in this study [34]. The results reported by ISIS show alkaline phosphatase and total bilirubin are lower in prairie dogs $>1$ year compared to prairie dogs $<1$ year which may partially explain the results of this study [38]. The long-term effects of decreased alkaline phosphatase, alanine aminotransferase, total bilirubin, and glucose are unknown.

A comparison of our results to those previously published indicates liver function was normal in prairie dogs during our study. All indicators of liver function except for glucose were within two reported ranges during both the pretreatment and post-treatment phases $[38,39]$. Post-treatment alkaline phosphatase was lower than the range reported by Keckler et al. [40]. Pretreatment glucose levels were within reported ranges, but post-treatment glucose levels were lower than reported ranges [39,41,42]. However, glucose levels were within the range reported by ISIS during both the pretreatment and post-treatment phases [38]. Two studies reported glucose ranges that were higher than those observed in this study $[43,44]$, and one reported ranges lower than those observed in this study [40]. Differences in glucose levels may be due to differences in the timing of feeding in relation to when blood samples were drawn.

GonaCon $^{\mathrm{TM}}$ did not alter indicators of kidney function except for blood urea nitrogen. Post-treatment levels of blood urea nitrogen were lower in treatment groups than in the control group. However, blood urea nitrogen levels increased during the posttreatment phase in all groups, including the control group. The most likely explanation for the treatment effect on blood urea nitrogen is the larger increase in the control group 6 months post-treatment. There was no clear effect of GonaCon ${ }^{\mathrm{TM}}$ dose on blood urea nitrogen. Hepatic insufficiency can decrease blood urea nitrogen, but no effects were found on liver function. Blood urea nitrogen can increase during the early stages of kidney disease when renal perfusion decreases, but many extrarenal factors such as diet can also falsely elevate blood urea nitrogen [45].

Both albumin and total protein were increased during the posttreatment phase. An increase in albumin tends to cause an increase in total protein [46]. Both can be falsely elevated due to hemolysis. However, hemolysis should also increase alkaline phosphatase, alanine aminotransferase, and phosphorus, none of which occurred in this study [36,47-50]. Albumin and total protein can also be elevated with dehydration, although animals had free access to water, apples, and carrots. The results reported by ISIS show alkaline phosphatase and total bilirubin are lower in prairie dogs $>1$ year compared to prairie dogs $<1$ year; therefore, age may explain the decrease observed in our study [38].

Indicators of kidney function were generally within reported ranges, suggesting kidney function was normal in prairie dogs during our study. Both albumin and amylase were within three previously reported ranges $[38,39,43]$. Total protein was within the ranges reported by ISIS [38] and Broughton [39] during both the 
pretreatment and post-treatment phases, but was higher during the post-treatment phase than the range reported by Pfeiffer et al. [43]. Creatinine was lower during both the pretreatment and posttreatment phases than the values reported by Pfeiffer et al. [43], but were similar to the ranges reported by ISIS [38] and Broughton [39]. Blood urea nitrogen was within the ranges reported by ISIS [38] and Broughton [39] for both the pretreatment and post-treatment phases. However, post-treatment blood urea nitrogen was higher than the ranges reported in three other studies $[40,41,43]$. Keckler et al. [40] reported lower ranges for albumin, creatinine, and total protein than those observed in this study.

GonaCon ${ }^{\mathrm{TM}}$ did not have an effect on electrolytes in this study. Although calcium levels were increased in the post-treatment phase, they were only increased by $0.2 \mathrm{mmol} / \mathrm{L}$ which is likely not biologically significant. Excess levels of vitamin D can increase calcium [51]. This seems unlikely given prairie dogs were housed indoors on a diet of carrots, apples, grass hay, and occasional rodent block. The amount of rodent block being fed was decreased toward the end of the study due to weight gains in most prairie dogs. Potassium levels were also increased during the post-treatment phase. Calcium and potassium levels can be artificially elevated due to hemolysis; however, as mentioned above, other indicators of hemolysis were not elevated. Potassium may also be elevated due to underlying renal disease, although no effects were observed on kidney enzymes [51].

A comparison of our results with those previously published in the literature also indicates electrolytes were normal in prairie dogs during our study. Calcium values were either similar to those reported previously in the literature [38-40], or lower than the reported range [43]. This suggests the slight increase observed in this study was still within normal range. Both pretreatment and post-treatment potassium values were similar to those reported for two laboratory studies, and to those reported for prairie dogs in the field $[39,40,52]$. Pretreatment potassium levels were similar to ranges reported by ISIS [38] and Pfeiffer et al. [43], but posttreatment levels were higher than these ranges. However, both pretreatment and post-treatment potassium levels were within the ranges reported by Keckler et al. [40]. Both pretreatment and posttreatment phosphorus and sodium levels were within reported ranges, although they were somewhat higher than those reported by Keckler et al. [38-40,52].

Body weights in all groups increased until 4 months posttreatment, then declined by approximately $50 \mathrm{~g}$ until 15 months post-treatment. This is most likely due to the reduction in the amount of rodent block being fed during the study. Treatment groups all had the same approximate mean body weight at the start of the study, and no treatment effects on body weight were found. Treatment effects on body weight might not be observed in the laboratory because all animals had the same access to food and shelter and were non-reproductive. Different results may be observed in the field. Likewise, GonaCon ${ }^{\mathrm{TM}}$ did not affect hematocrit.

Fewer prairie dogs were molting in the treated groups compared to the control group, but those that were molting had a higher percentage of hair loss than control animals. Statistical tests did not show significance despite the $400 \mu \mathrm{g}$ group having nearly twice the hair loss of the control group. However, standard deviations were very high making it unlikely statistical significance could be detected. A post hoc power analysis shows a sample size of 56 animals per group would be needed for $80 \%$ power at the lowest standard deviation observed in this study. One explanation for the results observed in this study may be that GonaCon ${ }^{\mathrm{TM}}$ delayed the timing of the molt slightly, such that treated animals were farther along in their molt than control animals. Because prairie dogs were only handled once a month, it is possible for the majority of the treated prairie dogs to have undergone and completed molting by the time we observed the hair loss. In a natural setting, this obser- vation should not adversely affect prairie dogs as they would have their winter pelage even before control animals.

GonaCon $^{\mathrm{TM}}$ is a safe contraceptive that was not associated with any adverse health effects in this study. The changes observed in blood chemistry in this study are most likely due to age or husbandry. Further studies need to be conducted to determine the effects of these factors on blood chemistry. GonaCon ${ }^{\mathrm{TM}}$ will not be associated with any nontarget hazards because it is injected. There are no secondary hazards associated with the vaccine because it is protein-based, and will be degraded in the gut of any animal consuming a vaccinated prairie dog.

Although animals must be captured to administer the vaccine, prairie dogs are relatively easy to trap. A concentrated trapping effort over a period of several days to a couple weeks will likely be sufficient to treat the majority of a colony. GonaCon ${ }^{\mathrm{TM}}$ will likely contracept prairie dogs for $\geq 1$ year in the field using either 200 or $400 \mu \mathrm{g}$ conjugate. It is recommended that $400 \mu \mathrm{g}$ be used in the field as antibody titers may last longer than the $200 \mu \mathrm{g}$ dose. Multiple years of contraception are desirable in this case so that animals do not have to be trapped yearly. A 2-year study with GonaCon ${ }^{\mathrm{TM}}$ in the field showed contraceptive effects at the $400 \mu \mathrm{g}$ dose, and analysis is ongoing [Yoder, unpublished results]. GonaCon ${ }^{\mathrm{TM}}$ could be incorporated into management plans to help maintain prairie dog populations while reducing habitat degradation due to overpopulation.

\section{Acknowledgments}

C. Denny, K. Crane, and R. Mauldin provided technical support. J. Eisemann and J. O'Hare provided comments on an earlier version of the manuscript.

\section{References}

[1] Fagerstone KA, Miller LA, Killian G, Yoder CA. Review of issues concerning the use of reproductive inhibitors, with particular emphasis on resolving humanwildlife conflicts in North America. Integr Zool 2010;1:15-30.

[2] Turner Jr JW, Kirkpatrick JF. Fertility control as a management tool for feral horse populations. J Equine Vet Sci 1986;6:278-84.

[3] Garrott RA. Effective management of free-ranging ungulate populations using contraception. Wildl Soc Bull 1995;23:445-52.

[4] Miller LA, Crane K, Gaddis S, Killian GJ. Porcine zona pellucida immunocontraception: long-term health effects on white-tailed deer. J Wildl Mange 2001;65:941-5.

[5] Killian G, Eisemann J, Wagner D, Werner J, Shaw D, Engeman R, et al. Safety and toxicity evaluation of GonaCon ${ }^{\mathrm{TM}}$ immunocontraceptive vaccine in whitetailed deer. Proc Vertebr Pest Conf 2006;22:82-7.

[6] Curtis PD, Richmond ME, Miller LA, Quimby FW. Physiological effects of gonadotropin-releasing hormone immunocontraception on white-tailed deer. Human-Wildl Conflicts 2008;2:68-79.

[7] Miller LA, John BE, Elias DJ, Crane KA. Comparative efficacy of two immunocontraceptive vaccines. Vaccine 1997;15:1858-62.

[8] Nash PB, James DK, Hui LT, Miller LA. Fertility control of California ground squirrels using GnRH immunocontraception. Proc Vertebr Pest Conf 2004;21:274-8.

[9] Miller B, Wemmer C, Biggins D, Reading R. A proposal to conserve black-footed ferrets and the prairie dog ecosystem. Environ Manage 1990;14:763-9.

[10] Miller B, Ceballos G, Reading R. The prairie dog and biotic diversity. Conserv Biol 1994;8:667-81.

[11] Miller B, Reading R, Hoogland J, Clark T, Ceballos G, List R, et al. The role of prairie dogs as a keystone species: response to Stapp. Conserv Biol 2000;14:318-21.

[12] Kotliar NB, Baker BW, Whicker AD, Plumb G. A critical review of assumptions about the prairie dog as a keystone species. Environ Manage 1999;24:177-92.

[13] Agnew W, Uresk DW, Hansen RM. Flora and fauna associated with prairie dog colonies and adjacent ungrazed mixed-grass prairie in western South Dakota. J Range Manage 1986;39:135-9.

[14] Lomolino MV, Smith GA. Prairie dog towns as islands: Applications of island biogeography and landscape ecology for conserving nonvolant terrestrial vertebrates. Glob Ecol Biogeogr 2003;12:275-86.

[15] Johnson WC, Collinge SK. Landscape effects on black-tailed prairie dog colonies. Biol Conserv 2004;115:487-97.

[16] Magle SB. Observations on body mass of prairie dogs in urban habitat. West $\mathrm{N}$ Am Nat 2008;68:113-8.

[17] Zinn HC, Andelt WF. Attitudes of Fort Collins, Colorado, residents toward prairie dogs. Wildl Soc Bull 1999;27:1098-106. 
[18] Witmer GW, VerCauteren KC, Manci KM, Dees DM. Urban-suburban prairie dog management: opportunities and challenges. Proc Vertebr Pest Conf 2000;19:439-44.

[19] Magle SB, Crooks KR. Investigating the distribution of prairie dogs in an urban landscape. Anim Conserv 2009;12:192-203.

[20] Fort Collins Natural Resources Division. Prairie dog policy for city natural areas. Fort Collins, CO, USA: Fort Collins Natural Resources Division; 1998.

[21] Franklin WL, Garrett MG. Nonlethal control of prairie dog colony expansion with visual barriers. Wildl Soc Bull 1989;17:426-30.

[22] Robinette KW, Andelt WF, Burnham KP. Effect of group size on survival of relocated prairie dogs. J Wildl Manage 1995;59:867-74.

[23] Andelt WF, Hopper SN. Managing prairie dogs. Colorado State University Cooperative Extension Bulletin Number 6.506, Fort Collins, Colorado, USA; 1998.

[24] Hygnstrom S. Plastic visual barriers were ineffective at reducing recolonization rates of prairie dogs. Proc Great Plains Wildl Damage Control Workshop 1996;12:74-6.

[25] Truett J, Dullman J, Matchett M, Owens E, Seery E. Translocating prairie dogs: a review. Wildl Soc Bull 2001;29:863-72.

[26] Witmer G, Gionfriddo J, Pipas M. Evaluation of physical barriers to prevent prairie dog colony expansion. Human-Wildl Conflicts 2008;2:206-11.

[27] Collins AR, Workman JP, Uresk DW. An economic analysis of black-tailed prairie dog (Cynomys ludovicianus) control. J Range Manage 1984;37:358-61.

[28] Knowles CJ. Population recovery of black-tailed prairie dogs following control with zinc phosphide. J Range Manage 1986;39:249-51.

[29] Cully Jr JF. Growth and life-history changes in Gunnison's prairie dogs after a plague epizootic. J Mammal 1997;78:146-57.

[30] Miller L, Rhyan J, Killian G. Evaluation of GnRH contraceptive vaccine using domestic swine as a model for feral hogs. Proc Wildl Damage Manage Conf 2003;10:120-7.

[31] SAS Institute. Version 9.1. Cary, NC, USA: SAS Institute; 2003.

[32] Saxton AM. A macro for converting mean separation output to letter groupings in PROC MIXED. Proc SAS Users Group Int 1998;23:1243-6. SAS Institute, Cary, NC, USA.

[33] Cornelius CE. Liver function. In: Kaneko JJ, editor. Clinical biochemistry of domestic animals. New York: Academic Press, Inc.; 1989. p. 364-97.

[34] Lassen ED. Laboratory evaluation of the liver. In: Thrall MA, Baker DC, Campbell TW, DeNicola D, Fettman MJ, Lassen ED, et al., editors. Veterinary hematology and clinical chemistry. Baltimore: Lippincott Williams and Wilkins; 2004. p. 355-75.

[35] Giannini EG, Testa R, Savarino V. Liver enzyme alteration: a guide for clinicians. CMAJ 2005; 172:367-79.

[36] Willard MD. Gastrointestinal, pancreatic, and hepatic disorders. In: Willard MD, Tvedten H, Turnwald GH, editors. Small animal clinical diagnosis by laboratory methods. Philadelphia: WB Saunders Company; 1989. p. 189-228.
[37] Waner T, Nyska A. The toxicological significance of decreased activities of blood alanine and aspartate aminotransferase. Vet Res Commun 1991;15: 73-8.

[38] ISIS. Reference ranges for physiological values in captive wildlife. CD-ROM. Apple Valley, Minnesota, USA: International Species Information System; 2002.

[39] Broughton GII. Hematologic and blood chemistry data for the prairie dog (Cynomys ludovicianus). Comp Biochem Physiol A 1992;101:807-12.

[40] Keckler MS, Gallardo-Romero NF, Langham GL, Damon IK, Karem KL, Carroll DS. Physiologic reference ranges for captive black-tailed prairie dogs (Cynomys ludovicianus). J Am Assoc Lab Anim Sci 2010;49:274-81.

[41] Fevold HR, Petersen TA. Liver glycogen and plasma insulin and glucagon levels in food- and water-deprived black-tailed prairie dogs (Cynomys ludovicianus). Comp Biochem Physiol A 1987;88:387-90.

[42] Stephens JR, Fevold HR. Biochemical adaptations in the black-tailed prairie dog (Cynomys ludovicianus) during long-term food and water deprivation. Comp Biochem Physiol A 1993;104:613-8.

[43] Pfeiffer EW, Teinking LN, Hamilton JD. Some effects of food and water deprivation on metabolism in black-tailed prairie dogs, Cynomys ludovicianus. Comp Biochem Physiol A 1979;63:19-22.

[44] Harlow HJ. Fasting biochemistry of representative spontaneous and facultative hibernators: the white-tailed prairie dog and the black-tailed prairie dog. Physiol Zool 1995;68:915-34.

[45] Willard MD. Urinary disorders. In: Willard MD, Tvedten H, Turnwald GH, editors. Small animal clinical diagnosis by laboratory methods. Philadelphia: WB Saunders Company; 1989. p. 121-53.

[46] Turnwald GH, Barta O. Immunologic and plasma protein disorders. In: Willard MD, Tvedten H, Turnwald GH, editors. Small animal clinical diagnosis by laboratory methods. Philadelphia: WB Saunders Company; 1989. p. 26482.

[47] Yücel D, Dalva K. Effect of in vitro hemolysis on 25 common biochemical tests. Clin Chem 1992;38:575-7.

[48] Kroll MH, Elin RJ. Interference with clinical laboratory analyses. Clin Chem 1994;40:1996-2005.

[49] Lippi G, Salvagno GL, Montagnana M, Brocco G, Guidi GC. Influence of hemolysis on routine clinical chemistry testing. Clin Chem Lab Med 2006;44:311-6.

[50] Lippi G, Blanckaert N, Bonini P, Green S, Kitchen S, Palicka V, et al. Haemolysis: an overview of the leading cause of unsuitable specimens in clinical laboratories. Clin Chem Lab Med 2008;46:764-72.

[51] Willard MD. Electrolyte and acid-base abnormalities. In: Willard MD, Tvedten $\mathrm{H}$, Turnwald GH, editors. Small animal clinical diagnosis by laboratory methods. Philadelphia: WB Saunders Company; 1989. p. 103-20.

[52] Bakko EB. Field water balance performance in prairie dogs (Cynomys leucurus and C. ludovicianus). Comp Biochem Physiol A 1977;56:443-51. 